\title{
The Role of the C-Clamp in Wnt-Related Colorectal Cancers
}

\author{
Aditi J. Ravindranath and Ken M. Cadigan * \\ Department of Molecular, Cellular and Developmental Biology, University of Michigan, Ann Arbor, \\ MI 48109, USA; aditir@umich.edu \\ * Correspondence: cadigan@umich.edu; Tel.: +1-734-647-5776
}

Academic Editors: Renée van Amerongen and Walter Birchmeier

Received: 9 May 2016; Accepted: 29 July 2016; Published: 3 August 2016

\begin{abstract}
T-cell Factor/Lymphoid Enhancer Factor (TCF/LEF) transcription factors are major regulators of Wnt targets, and the products of the TCF7 and TCF7L2 genes have both been implicated in the progression of colorectal cancer in animal models and humans. TCFs recognize specific DNA sequences through their high mobility group (HMG) domains, but invertebrate TCFs and some isoforms of vertebrate TCF7 and TCF7L2 contain a second DNA binding domain known as the C-clamp. This review will cover the basic properties of C-clamps and their importance in Wnt signaling, using data from Drosophila, C. elegans, and mammalian cell culture. The connection between C-clamp containing TCFs and colorectal cancer will also be discussed.
\end{abstract}

Keywords: TCF/LEF; C-clamp; Wnt; $\beta$-catenin; colorectal cancer

\section{Introduction to the TCF Family}

The T-cell Factor/Lymphoid Enhancer Factor (TCF/LEF; hereafter referred to as TCF) family of transcription factors are major nuclear mediators of the Wnt $/ \beta$-catenin signaling pathway [1-3]. In Drosophila, depletion of the sole TCF gene (TCF/Pangolin or TCF/Pan) results in severe patterning defects in the embryo and larval imaginal discs, indicative of loss of Wnt signaling [4-6]. Similarly, in C. elegans, the single TCF gene POP-1 has similar phenotypes to Wnt or $\beta$-catenin mutants in gonadal stem cell specification and left $Q(Q L)$ neuroblast migration [7,8], and regulates Wnt transcriptional targets in early embryogenesis [9-12]. While there is evidence that TCF is the predominant transcription factor in the Wnt pathway in invertebrates, the situation is less clear in vertebrates. No vertebrate TCF loss-of-function mutant has been found that resembles the gastrulation defect phenotype seen in mutants of other positive acting factors in the Wnt pathway-e.g., Wnt3, $\beta$-catenin, and LRP5, LRP6 double mutants [2]. While this could be due to redundancy among different mammalian TCFs, there is also a growing list of non-TCF transcription factors (e.g., FOXO and SOX proteins and nuclear receptors) which have the ability to bind $\beta$-catenin and activate transcriptional targets $[1,2,13,14]$. While these complexities need to be resolved, this chapter will focus on the TCF family of proteins in Wnt-dependent gene regulation.

Unlike invertebrates, which typically have a single TCF ortholog, mammals have four TCF genes: TCF7 (also known as TCF1), LEF1, TCF7L1 (also known as TCF3), and TCF7L2 (also known as TCF4) [1,2]. Additional diversity comes from the fact that mammalian TCF genes undergo extensive alternative splicing and have multiple promoters [2]. LEF1 is primarily known as a transcriptional activator of Wnt target genes $[15,16]$, while TCF7L1 appears to act mainly as a repressor $[15,17]$. TCF7 and TCF7L2 can act as both activators and repressors of Wnt targets, depending on the context $[15,18,19]$. TCFs - particularly TCF7 and TCF7L2-have been implicated across different tumor types [20-22], with a particularly strong link to colorectal cancer [18,23-26]. 
All TCF family members share two highly-conserved domains: the $\beta$-catenin binding domain and the High Mobility Group (HMG) DNA-binding domain [2]. Originally discovered through yeast two-hybrid screens, the $\mathrm{N}$-terminal $\beta$-catenin binding domain interacts with the intracellular messenger $\beta$-catenin, which translocates from the cytoplasm to the nucleus upon Wnt stimulation $[6,27,28]$. Deletion of this domain creates a dominant negative version of TCF, presumably by outcompeting endogenous TCFs for binding to target sites on chromatin [6,28]. Such dominant negative isoforms occur naturally for TCF7, LEF1, and TCF7L2, where they play physiologically relevant roles in antagonizing $W n t / \beta$-catenin signaling [29-32].

The HMG domains found in TCFs belong to the HMGB subgroup of the larger HMG superfamily [33,34]. These HMG domains are comprised of three $\alpha$-helices, which interact with DNA through minor groove contacts and cause a DNA bend between $90^{\circ}$ and $130^{\circ}$ [35,36]. An adjacent basic tail C-terminal to the third $\alpha$-helix also contributes to this binding and bending [35]. Interestingly, the HMG domain of LEF1 is significantly disordered in solution, only adopting its full helical structure when complexed with DNA [37]. The HMG domains of invertebrate and vertebrate TCFs are highly conserved [1], and all family members preferentially bind a consensus in vitro defined by SCTTTGATS $(S=G / C)[6,38,39]$. In vivo, these sites have been found in many Wnt-responsive enhancers $[1,40]$, and this motif is enriched in TCF7L2 and $\beta$-catenin binding peaks in chromatin immunoprecipitation experiments [41-43].

\section{The C-Clamp: Biochemical Properties and Functional Roles}

Many TCFs also contain a second DNA binding domain, termed the cysteine clamp or C-clamp, which is C-terminal to the HMG domain (Figure 1). Originally discovered by Waterman and colleagues, the C-clamp is present in most invertebrate TCFs as well as the so-called E-tail-containing isoforms of the vertebrate TCF7 and TCF7L2 [39] —hereafter referred to as TCF1E and TCF4E. In vertebrate TCFs, the E-tail is one of several alternatively spliced patterns corresponding to the C-terminal portion of TCF7 and TCF7L2 [44,45]. In addition to TCF1E and TCF4E isoforms, many other TCF7 and TCF7L2 isoforms lack the C-clamp, and some contain a truncated C-clamp [46] (Figure 2).

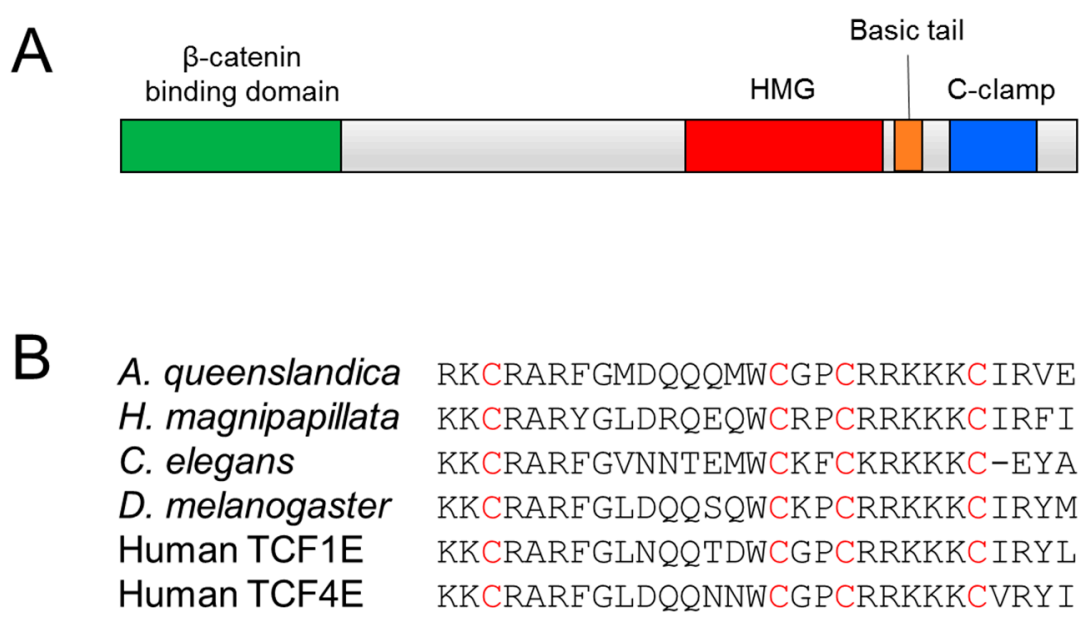

Figure 1. Conserved domains of the T-cell Factor/Lymphoid Enhancer Factor (TCF) family of transcription factors. (A) Schematic of a generic TCF, showing the $\beta$-catenin binding domain (green), the high mobility group (HMG) domain (red), the basic tail (orange), and the C-clamp (blue). The first three motifs are found in all TCFs, with the C-clamp being present in most invertebrate TCFs and in some vertebrate TCF1E and TCF4E isoforms; (B) Alignment of the C-clamps across metazoan TCFs. Sequences from four invertebrate TCFs and human TCF1E and TCF4E are included. Conserved cysteine residues across the 6 sequences are highlighted in red. 


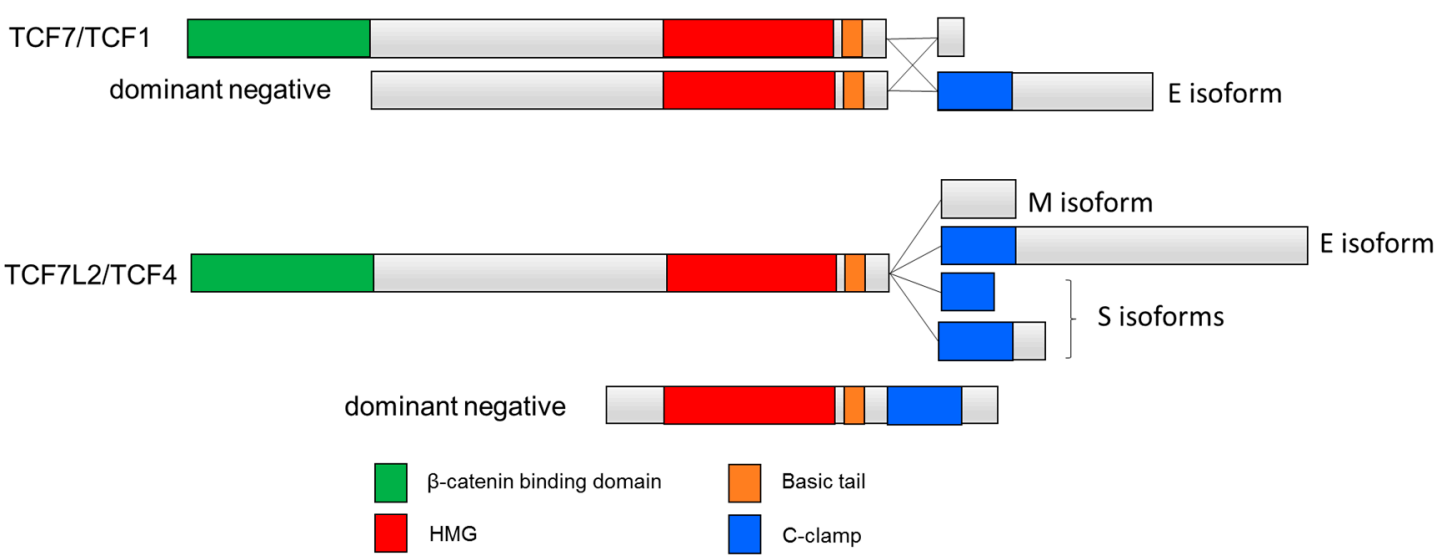

Figure 2. C-clamp containing human TCF isoforms. Inclusion of the C-clamp is seen in the E-tail-containing isoforms TCF1E and TCF4E. Other isoforms include M isoforms that lack the C-clamp and $\mathrm{S}$ isoforms that contain a truncated C-clamp [46]. Dominant negative isoforms dnTCF7 and dnTCF7L2 lack the $\beta$-catenin binding domain.

The C-clamp gets its name from its hallmark of four highly-conserved cysteines (Figure 1) [39]. While the crystal structure of the C-clamp is yet to be determined, there is convincing evidence that the C-clamp forms a DNA-binding zinc finger domain. The C-clamp's DNA binding activity requires the presence of a zinc ion, and recombinant $\mathrm{C}$-clamp contains near-stoichiometric quantities of zinc [47]. In addition, mutation of any of the four cysteines results in a non-functional C-clamp [39,47-49]. In this way, the C-clamp is similar to the four cysteine treble clef zinc fingers found in nuclear receptors [50]. However, the spacing of the cysteine residues of the C-clamp is distinct from treble clef zinc fingers [47]. Even compared to the entire family of zinc finger motifs [51,52], the Cys- $\mathrm{X}_{12}$-Cys- $\mathrm{X}_{2}-\mathrm{Cys}-\mathrm{X}_{5}$-Cys spacing of C-clamps is distinct from all other classes (Figure 3). In addition to the cysteines, two stretches of basic amino acid residues-the first adjacent to the first cysteine and the second between the third and fourth cysteines-contribute to both DNA binding and activation of a reporter construct in cell culture [47]. Based on the available data, one can envision that the C-clamp is a zinc-finger domain that makes direct contacts with the DNA phosphate backbone and base pairs through its basic residue stretches.

$\mathrm{C} 2 \mathrm{H} 2$
Zn2/Cys6
Gag knuckle
Zinc ribbon
TAZ2 domain-like
Treble Clef
C-clamp

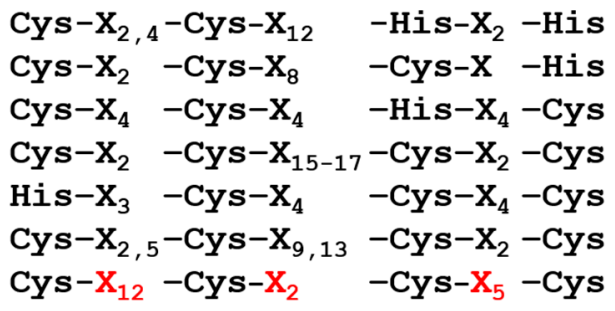

Figure 3. The spacing of cysteine residues in the C-clamp is unique and distinct from other zinc finger motifs. In all six zinc-finger superfamilies, the spacing between the zinc-coordinating residues (Cys or His) is even (Gag knuckle and TAZ2 domain-like) or a pattern where the first two and last two Cys/His residues are close together, separated by a larger stretch of amino acids. The C-clamp is unique in that there are twelve residues between the first and second Cys residues, and only two between the second and third. The unique number of residues between the cysteine residues in the C-clamp are highlighted in red. See text for further explanation.

Like the HMG domain, the C-clamp can recognize DNA in a sequence-specific manner. The presence of a C-clamp in mammalian TCF1E and TCF4E allows these proteins to recognize a motif of RCCG in addition to the classic HMG binding site [39,46,53]. In Drosophila, the C-clamp of 
TCF/Pan is necessary and sufficient for binding to a GC-rich motif, referred to as the Helper site [47,48]. In flies, the Helper site consensus is GCCGCCR $(R=A / G)$, while the slightly divergent C-clamp of C. elegans POP-1 has a consensus of GCCRAnW (W = A/T) [54]. Helper sites are found near functional HMG sites in more than a dozen Wnt-responsive enhancers in flies and worms, and mutation of these Helper sites abolishes activation by the Wnt pathway [48,54,55]. Helper-like RCCG motifs are found in the regulatory DNA of mammalian LEF1 and CDX1 genes, which require an intact C-clamp for activation by Wnt signaling $[39,56]$. Helper-like sites have also been found in the promoter regions of several other human Wnt targets [42,53], including genes (e.g., SP5, CDX2, and MYC) that are upregulated in colorectal cancer (CRC) $[49,53]$. Taken together, the data support a model where the DNA binding specificity of TCFs is enhanced by the presence of a C-clamp, which allows bipartite recognition via HMG domain-HMG site and C-clamp-Helper site interactions [2,55].

In addition to enhancing DNA specificity, the architecture of HMG-Helper site pairs also contributes to more nuanced transcriptional regulation of Wnt-regulated enhancers. The spacing and orientation of these motifs were systemically examined for TCF/Pan. Some constraints were identified (i.e., two of the four possible orientations were preferentially bound by TCF/Pan), but there was also a remarkable level of flexibility in DNA recognition, with the presence of a Helper site in any orientation near a HMG site improving TCF binding and Wnt target activation [55]. This is possibly due to the ability of the HMG domain to bend DNA, which may allow the C-clamp to "swing" and interact with Helper sites located upstream or downstream of HMG sites (Figure 4). In addition, the semi-palindromic nature of Helper sites makes it difficult to unambiguously define whether a HMG-Helper pair has a tandem or inverted orientation [55]. Interestingly, the orientation of HMG-Helper site pairs in transgenic fly reporter assays had a profound effect on the tissue specificity of Wnt-dependent transcriptional activation [55]. While the mechanism of this mode of regulation remains to be determined, it is worth noting that in mammalian Wnt targets, functional Helper sites can be either upstream or downstream of their cognate HMG sites [49,53].
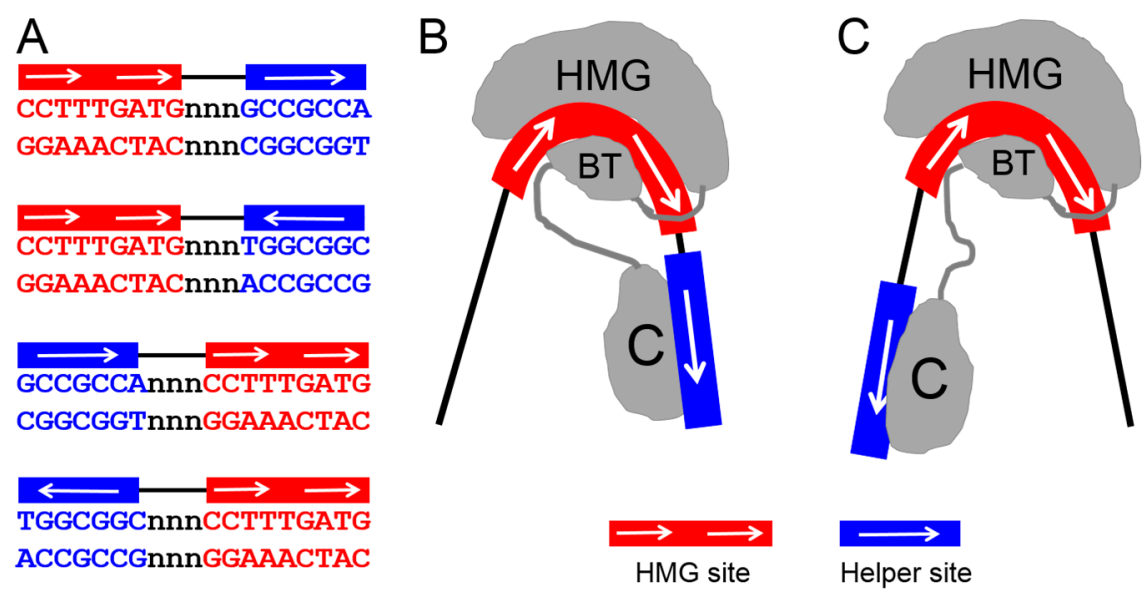

Figure 4. Bipartite but flexible DNA recognition model for TCF. TCF/Pan recognizes DNA through simultaneous HMG domain-HMG site and C-clamp-Helper site interactions. (A) Sequence of the four possible HMG-Helper site configurations. All four orientations increase binding affinity over HMG sites alone [55], and have biological activity in some cells [49,55]; (B,C) A model that can explain how a single TCF molecule can bind to all four orientations. The ability of the HMG domain to dramatically bend DNA [35] could allow the C-clamp to reach Helper sites either downstream (B) or upstream (C) of the HMG site. In addition, the semi-palindromic nature of the Helper site (A) can explain how either orientation can be recognized in a HMG-Helper site pair. Figure adapted from Archbold et al. [55].

TCFs are thought to regulate many Wnt targets through a transcriptional switch mechanism, and there is data indicating that this regulation involves differential use of Helper sites. In this model, 
targets are repressed in the absence of signaling by TCF-dependent recruitment of co-repressors to Wnt target gene chromatin [3,57]. $\beta$-catenin binding to TCF inactivates or displaces co-repressors and recruits co-activators to the complex, leading to transcriptional activation. In Drosophila and C. elegans, where a single TCF is responsible for both basal repression and $\beta$-catenin-dependent activation, activation of Wnt targets requires both HMG and Helper sites [54]. While HMG sites also mediate basal repression, the C-clamp-Helper site interaction was found to be dispensable for TCF-dependent repression in the absence of Wnt signaling [54]. It is interesting to note that in vertebrates, TCF7L1, whose isoforms do not contain a C-clamp, is thought to mediate the majority of basal repression of Wnt targets [15,17,58-61].

In addition to the classic TCF transcriptional switch, another type of switch has been described in Drosophila hematopoietic cells for genes that are repressed by Wnt/ $\beta$-catenin signaling. In these cases, TCF/Pan activates the gene's expression in the absence of signaling, while $\beta$-catenin promotes transcriptional repression [62,63]. The TCF binding sites mediating this "reverse transcriptional switch" are distinct from classic ones, with the HMG domain site having the consensus WGAWAW for HMG sites and the Helper sites KCCSSNWW $(K=G / T)$ [63]. These novel sites are instructive, in that a Wnt-repressed element can be converted to an activated one simply by swapping the novel HMG and Helper sites to the classic consensus, and vice versa-i.e., an activated element can be converted to a repressed element by converting the sites to the novel consensus [63]. Both the HMG and Helper sites must be swapped in order to achieve this dramatic reprogramming of the transcriptional output. These data support a model where TCF and the TCF- $\beta$-catenin complex are allosterically regulated by the specific HMG/Helper sites it associates with, influencing the subsequent recruitment of additional co-regulators [63].

It is important to note that the above-mentioned DNA binding properties of TCF have been studied primarily in invertebrates. However, the primary sequences of the HMG and C-clamps of TCF1E and TCF4E are very similar to TCF/Pan (Figure 1), suggesting that they share similar biochemical properties. While this needs to be investigated more directly, several specific Wnt target genes (many of which are associated with oncogenesis) require TCF1E and TCF4E isoforms for Wnt-dependent expression $[39,46,49,53,56,64]$.

\section{Other C-Clamp Containing Proteins}

In addition to TCF1E and TCF4E, the C-clamp is present in three other proteins in mammalian genomes [65-68]. The best characterized are Huntington Disease Binding Proteins (HDBP) 1 and 2 , both of which have been associated with Huntington's Disease [67]. HDBP1 is also known as SLC2A4 regulator (SLC2A4RG) or GLUT4 enhancer factor (GLUT4EF) [69,70], and have been linked to increased risk of intestinal disorders [71,72]. In addition to TCF/Pan, Drosophila has only one other C-clamp-containing protein, known as fly Glut4EF, which regulates wing position in adult flies [73]. HDBP2 - more commonly known as ZNF395- has also been implicated in various human cancers, although in conflicting roles. It's thought to act as an oncogene, since elevated levels of this transcription factor may support cancer progression in hypoxia-induced cancers, such as glioblastomas and neuroblastomas, through the innate immune response pathway [74]. However, evidence in liver and breast cancer cell lines suggest a tumor suppressor role for ZNF395, potentially via repression of a pro-metastatic gene expression program [75,76]. The third C-clamp protein, known as ZNF704 or glucocorticoid induced gene (GIG1) [68] has recently been suggested to be a candidate for a factor influencing human longevity [77].

\section{The Role of C-Clamp Containing TCFs in Colorectal Cancer}

Elevated Wnt signaling is thought to be oncogenic in many human cancers, but perhaps the most compelling case is in CRC [78,79]. TCF7L2 is a major player in regulating Wnt transcriptional targets in this context [80]. This is supported by mouse genetics, where TCF7L2 whole animal or conditional knockouts result in a loss of proliferative capacity of the intestinal epithelia [81,82]. In several CRC cell 
lines, expression of a dominant negative TCF7L2 (i.e., lacking the $\beta$-catenin binding domain) or siRNA knockdown of TCF7L2 inhibits growth and results in apoptosis $[26,83]$. Consistent with a positive role in Wnt signaling, some CRCs contain a recurring TCF7L2 fusion that presumably allows it to activate transcription in a $\beta$-catenin-independent manner [84].

While the short summary above reflects the prevailing view [85], it should be noted that there are also reports supporting a role for TCF7L2 repressing Wnt signaling [18] and acting as a tumor suppressor in a mouse model of CRC [23]. While these discrepancies could be explained by differences in the experimental protocols $[82,83]$, it is also possible that TCF7L2 mediates both sides of the TCF transcriptional switch, and one or the other activity is emphasized in a given study.

TCF7 has also been implicated in CRC and intestinal biology, acting in an antagonistic manner to TCF7L2. In non-pathological conditions, intestinal cells largely express a truncated TCF7 from an intronic promoter, producing a protein lacking the $\mathrm{N}$-terminal $\beta$-catenin binding domain (dnTCF7) [25,29,45]. Depletion of TCF7 resulted in an increase in adenoma formation in the adult gut and markedly increased tumor incidence in multiple intestinal neoplasia (min) mice, which are heterozygous for a stop codon in the tumor suppressor gene APC $\left(A p c^{m i n}\right)$ [29]. Presumably, loss of dnTCF7 allows TCF7L2 to drive the Wnt pro-proliferative transcriptional program in these cells $[25,29]$.

At odds with the mouse knockout data, TCF7 has also been reported to have an oncogenic role in one CRC cell line [18]. One explanation for this discrepancy comes from a study by Waterman and colleagues, who demonstrated a dramatic difference in TCF7 isoform expression and subcellular localization between normal and CRC cells [25]. While normal cells contain mostly nuclear dnTCF7, CRC cells have decreased expression of dnTCF7 and a dramatic increase in the expression of full length TCF7. This TCF7 resides largely in the cytoplasm. This subcellular localization is regulated by a Calmodulin-dependent kinase II (CamKII)-Wnt-CamKII feed-forward loop [25]. The authors suggest that this regulation can explain the dual role of TCF7 in CRC, where TCF7 is converted from a tumor suppressor to an oncogene by Wnt and CamKII signaling [25].

While most studies on the role of TCF7 and TCF7L2 in CRC do not indicate whether the isoform used contains a C-clamp, Waterman and colleagues have examined this issue in some detail. Originally, they noted that TCF1E and TCF4E could specifically activate reporters containing regulatory DNA from the Lef1 and $C d x 1$ promoters $[56,86]$. Subsequent work indicated that a functional C-clamp was required for this regulation $[39,49]$. Overexpression of dnTCF7 had previously been associated with stalling of the G1 to $S$ phase transition in CRC cells, in a p21-dependent manner [26]. This effect of dnTCF7 is dependent on the presence of the C-clamp [39]. Transcriptome analysis of CRC cells expressing dnTCF7 with a functional or mutant C-clamp demonstrated that the regulation of many Wnt targets is C-clamp dependent. Several of these C-clamp-specific targets are inhibitors of p21 (e.g., SP5, TGIF, YAP1), suggesting a model where C-clamp containing TCF activates their expression to bypass a p21 block in the cell cycle of CRC cells [49]. Transcriptional regulation of one of these target genes, SP5, was found to be dependent on C-clamp-Helper site interactions, suggesting a direct role for the C-clamp in the modulation of the cell cycle in intestinal cancer cells [49]. This was extended to a genomic level by ChiP-seq experiments with TCF7 with or without the C-clamp, which support the view that many biologically important Wnt targets in CRC are C-clamp/Helper site dependent [53]. Consistent with this, most dnTCF7 in intestinal cells contains a C-clamp [25].

Another research group explored a broader role for the C-clamp across multiple cancers through transcriptional regulation of the TMEPAI (transmembrane prostate androgen-induced RNA) gene [87]. TMEPAI activation is dependent on both the TGF- $\beta$ and Wnt pathways [88], and TMEPAI has been implicated in intestinal polyp formation in $\mathrm{Apc}^{\mathrm{Min} /+}$ mice $[89,90]$, as well as in human breast cancer, colon cancer, renal cell carcinoma, and lung adenocarcinoma [91-94]. Nakano and colleagues found that only E isoforms of TCFs efficiently activated a TMEPAI reporter construct in the presence of TGF- $\beta$ stimulation, but not isoforms lacking this domain [87]. Moreover, TCF7L2 mutants with either a C-clamp deletion or C-clamp point mutation (C463A) were no longer able to potentiate reporter activity, indicating that the C-clamp is necessary for this regulation [87]. 


\section{Final Perspective}

While the importance of the C-clamp in Wnt/TCF regulation of CRC remains to be established, the existing data indicates that more attention needs to be paid to this DNA binding domain. For example, one recent report on the reciprocal regulation of TCF7L2 and the transcription factor ZEB1 in CRC progression utilized a TCF7L2 isoform containing the C-clamp, but failed to consider whether this domain played a role in the regulation of several Wnt target genes [95]. Moving forward, testing the function of TCF7L2 isoforms with and without the C-clamp in the regulation of specific targets should become the standard.

A rigorous test of the C-clamp's importance in Wnt transcriptional regulation would be to engineer a mouse mutant where the TCF1E or TCF4E isoforms are not expressed. Deletion of the C-clamp-containing exon 9 in the TCF7 locus [45], and exons 14 and 15 in TCF7 [46] would generate such a double TCF1E, TCF4E knockout. TCF7 and TCF7L2 compound null mouse embryos exhibit severe hindgut defects, with anterior transformation of the gastrointestinal tract [96]. It is tempting to speculate that TCF1E, TCF4E mutants would display more nuanced phenotypes. If these mice had normal intestines, they could be placed in CRC mouse models such as $A p c^{\text {min }}$ [97], or mice carrying a CDX2P-NLS Cre recombinase transgene and a loxP-targeted Apc allele [98]. Crossing a TCF1E, TCF4E double mutant into either background could provide important insights into the tumor-promoting versus tumor-suppressing roles of C-clamp-containing TCF isoforms.

Acknowledgments: The authors thank Abhishek Sinha for comments on the manuscript. This work was supported by NIH grant GM108468 to KMC.

Conflicts of Interest: The authors declare no conflict of interest.

\section{References}

1. Archbold, H.C.; Yang, Y.X.; Chen, L.; Cadigan, K.M. How do they do Wnt they do? Regulation of transcription by the Wnt/beta-catenin pathway. Acta Physiol. (Oxf.) 2012, 204, 74-109. [CrossRef] [PubMed]

2. Cadigan, K.M.; Waterman, M.L. TCF/LEFs and Wnt signaling in the nucleus. Cold Spring Harb. Perspect. Biol. 2012, 4, a007906. [CrossRef] [PubMed]

3. Cadigan, K.M. TCFs and Wnt/beta-catenin signaling: More than one way to throw the switch. Curr. Top. Dev. Biol. 2012, 98, 1-34. [PubMed]

4. Brunner, E.; Peter, O.; Schweizer, L.; Basler, K. Pangolin encodes a Lef-1 homologue that acts downstream of armadillo to transduce the wingless signal in Drosophila. Nature 1997, 385, 829-833. [CrossRef] [PubMed]

5. Schweizer, L.; Nellen, D.; Basler, K. Requirement for Pangolin/dTCF in Drosophila wingless signaling. Proc. Natl. Acad. Sci. USA 2003, 100, 5846-5851. [CrossRef] [PubMed]

6. Van de Wetering, M.; Cavallo, R.; Dooijes, D.; van Beest, M.; van Es, J.; Loureiro, J.; Ypma, A.; Hursh, D.; Jones, T.; Bejsovec, A.; et al. Armadillo coactivates transcription driven by the product of the drosophila segment polarity gene dtcf. Cell 1997, 88, 789-799. [CrossRef]

7. Lam, N.; Chesney, M.A.; Kimble, J. Wnt signaling and CEH-22/tinman/Nkx2.5 specify a stem cell niche in C. elegans. Curr. Biol. 2006, 16, 287-295. [CrossRef] [PubMed]

8. Herman, M. C. elegans pop- $1 / \mathrm{tcf}$ functions in a canonical Wnt pathway that controls cell migration and in a noncanonical Wnt pathway that controls cell polarity. Development 2001, 128, 581-590. [PubMed]

9. Huang, S.; Shetty, P.; Robertson, S.M.; Lin, R. Binary cell fate specification during C. elegans embryogenesis driven by reiterated reciprocal asymmetry of TCF POP-1 and its coactivator beta-catenin SYS-1. Development 2007, 134, 2685-2695. [CrossRef] [PubMed]

10. Lin, R.; Thompson, S.; Priess, J.R. POP-1 encodes an HMG box protein required for the specification of a mesoderm precursor in early C. elegans embryos. Cell 1995, 83, 599-609. [CrossRef]

11. Maduro, M.F.; Kasmir, J.J.; Zhu, J.; Rothman, J.H. The Wnt effector POP-1 and the PAL-1/caudal homeoprotein collaborate with SKN-1 to activate C. elegans endoderm development. Dev. Biol. 2005, 285, 510-523. [CrossRef] [PubMed] 
12. Shetty, P.; Lo, M.C.; Robertson, S.M.; Lin, R. C. elegans TCF protein, POP-1, converts from repressor to activator as a result of Wnt-induced lowering of nuclear levels. Dev. Biol. 2005, 285, 584-592. [CrossRef] [PubMed]

13. Mulholland, D.J.; Dedhar, S.; Coetzee, G.A.; Nelson, C.C. Interaction of nuclear receptors with the Wnt/beta-catenin/Tcf signaling axis: Wnt you like to know? Endocr. Rev. 2005, 26, 898-915. [CrossRef] [PubMed]

14. Valenta, T.; Hausmann, G.; Basler, K. The many faces and functions of beta-catenin. EMBO J. 2012, 31, 2714-2736. [CrossRef] [PubMed]

15. Liu, F.; van den Broek, O.; Destree, O.; Hoppler, S. Distinct roles for Xenopus Tcf/Lef genes in mediating specific responses to Wnt/beta-catenin signalling in mesoderm development. Development 2005, 132, 5375-5385. [CrossRef] [PubMed]

16. Kratochwil, K.; Galceran, J.; Tontsch, S.; Roth, W.; Grosschedl, R. FGF4, a direct target of LEF1 and Wnt signaling, can rescue the arrest of tooth organogenesis in Lef1(-/-) mice. Genes Dev. 2002, 16, 3173-3185. [CrossRef] [PubMed]

17. Merrill, B.J.; Pasolli, H.A.; Polak, L.; Rendl, M.; Garcia-Garcia, M.J.; Anderson, K.V.; Fuchs, E. Tcf3: A transcriptional regulator of axis induction in the early embryo. Development 2004, 131, 263-274. [CrossRef] [PubMed]

18. Tang, W.; Dodge, M.; Gundapaneni, D.; Michnoff, C.; Roth, M.; Lum, L. A genome-wide rnai screen for Wnt/beta-catenin pathway components identifies unexpected roles for TCF transcription factors in cancer. Proc. Natl. Acad. Sci. USA 2008, 105, 9697-9702. [CrossRef] [PubMed]

19. Standley, H.J.; Destree, O.; Kofron, M.; Wylie, C.; Heasman, J. Maternal XTcf1 and XTcf4 have distinct roles in regulating Wnt target genes. Dev. Biol. 2006, 289, 318-328. [CrossRef] [PubMed]

20. Grumolato, L.; Liu, G.; Haremaki, T.; Mungamuri, S.K.; Mong, P.; Akiri, G.; Lopez-Bergami, P.; Arita, A.; Anouar, Y.; Mlodzik, M.; et al. Beta-catenin-independent activation of TCF1/LEF1 in human hematopoietic tumor cells through interaction with ATF2 transcription factors. PLoS Genet. 2013, 9, e1003603. [CrossRef] [PubMed]

21. Ravindranath, A.; Yuen, H.F.; Chan, K.K.; Grills, C.; Fennell, D.A.; Lappin, T.R.; El-Tanani, M. Wnt-beta-catenin-Tcf-4 signalling-modulated invasiveness is dependent on osteopontin expression in breast cancer. Br. J. Cancer 2011, 105, 542-551. [CrossRef] [PubMed]

22. Slyper, M.; Shahar, A.; Bar-Ziv, A.; Granit, R.Z.; Hamburger, T.; Maly, B.; Peretz, T.; Ben-Porath, I. Control of breast cancer growth and initiation by the stem cell-associated transcription factor TCF3. Cancer Res. 2012, 72, 5613-5624. [CrossRef] [PubMed]

23. Angus-Hill, M.L.; Elbert, K.M.; Hidalgo, J.; Capecchi, M.R. T-cell factor 4 functions as a tumor suppressor whose disruption modulates colon cell proliferation and tumorigenesis. Proc. Natl. Acad. Sci. USA 2011, 108, 4914-4919. [CrossRef] [PubMed]

24. Korinek, V.; Barker, N.; Morin, P.J.; van Wichen, D.; de Weger, R.; Kinzler, K.W.; Vogelstein, B.; Clevers, H. Constitutive transcriptional activation by a beta-catenin-tcf complex in APC - / - colon carcinoma. Science 1997, 275, 1784-1787. [CrossRef] [PubMed]

25. Najdi, R.; Syed, A.; Arce, L.; Theisen, H.; Ting, J.H.; Atcha, F.; Nguyen, A.V.; Martinez, M.; Holcombe, R.F.; Edwards, R.A.; et al. A Wnt kinase network alters nuclear localization of TCF-1 in colon cancer. Oncogene 2009, 28, 4133-4146. [CrossRef] [PubMed]

26. van de Wetering, M.; Sancho, E.; Verweij, C.; de Lau, W.; Oving, I.; Hurlstone, A.; van der Horn, K.; Batlle, E.; Coudreuse, D.; Haramis, A.P.; et al. The beta-catenin/TCF-4 complex imposes a crypt progenitor phenotype on colorectal cancer cells. Cell 2002, 111, 241-250. [CrossRef]

27. Behrens, J.; von Kries, J.P.; Kuhl, M.; Bruhn, L.; Wedlich, D.; Grosschedl, R.; Birchmeier, W. Functional interaction of beta-catenin with the transcription factor LEF-1. Nature 1996, 382, 638-642. [CrossRef] [PubMed]

28. Molenaar, M.; van de Wetering, M.; Oosterwegel, M.; Peterson-Maduro, J.; Godsave, S.; Korinek, V.; Roose, J.; Destree, O.; Clevers, H. XTcf-3 transcription factor mediates beta-catenin-induced axis formation in xenopus embryos. Cell 1996, 86, 391-399. [CrossRef]

29. Roose, J.; Huls, G.; van Beest, M.; Moerer, P.; van der Horn, K.; Goldschmeding, R.; Logtenberg, T.; Clevers, H. Synergy between tumor suppressor APC and the beta-catenin-Tcf4 target Tcf1. Science 1999, 285, $1923-1926$. [CrossRef] [PubMed]

30. Kennell, J.A.; O'Leary, E.E.; Gummow, B.M.; Hammer, G.D.; MacDougald, O.A. T-cell factor 4N (TCF-4N), a novel isoform of mouse TCF-4, synergizes with beta-catenin to coactivate C/EBPalpha and steroidogenic factor 1 transcription factors. Mol. Cell. Biol. 2003, 23, 5366-5375. [CrossRef] [PubMed] 
31. Vacik, T.; Lemke, G. Dominant-negative isoforms of Tcf/Lef proteins in development and disease. Cell Cycle 2011, 10, 4199-4200. [CrossRef] [PubMed]

32. Vacik, T.; Stubbs, J.L.; Lemke, G. A novel mechanism for the transcriptional regulation of Wnt signaling in development. Genes Dev. 2011, 25, 1783-1795. [CrossRef] [PubMed]

33. Malarkey, C.S.; Churchill, M.E. The high mobility group box: The ultimate utility player of a cell. Trends Biochem. Sci. 2012, 37, 553-562. [CrossRef] [PubMed]

34. Stros, M. HMGB proteins: Interactions with DNA and chromatin. Biochim. Biophys. Acta 2010, 1799, $101-113$. [CrossRef] [PubMed]

35. Love, J.J.; Li, X.; Case, D.A.; Giese, K.; Grosschedl, R.; Wright, P.E. Structural basis for DNA bending by the architectural transcription factor LEF-1. Nature 1995, 376, 791-795. [CrossRef] [PubMed]

36. Giese, K.; Amsterdam, A.; Grosschedl, R. DNA-binding properties of the hmg domain of the lymphoid-specific transcriptional regulator LEF-1. Genes Dev. 1991, 5, 2567-2578. [CrossRef] [PubMed]

37. Love, J.J.; Li, X.; Chung, J.; Dyson, H.J.; Wright, P.E. The LEF-1 high-mobility group domain undergoes a disorder-to-order transition upon formation of a complex with cognate DNA. Biochemistry 2004, 43, 8725-8734. [CrossRef] [PubMed]

38. Van Beest, M.; Dooijes, D.; van De Wetering, M.; Kjaerulff, S.; Bonvin, A.; Nielsen, O.; Clevers, H. Sequence-specific high mobility group box factors recognize 10-12-base pair minor groove motifs. J. Biol. Chem. 2000, 275, 27266-27273. [PubMed]

39. Atcha, F.A.; Syed, A.; Wu, B.; Hoverter, N.P.; Yokoyama, N.N.; Ting, J.H.; Munguia, J.E.; Mangalam, H.J.; Marsh, J.L.; Waterman, M.L. A unique DNA binding domain converts T-cell factors into strong wnt effectors. Mol. Cell. Biol. 2007, 27, 8352-8363. [CrossRef] [PubMed]

40. Barolo, S. Transgenic Wnt/TCF pathway reporters: All you need is Lef? Oncogene 2006, 25, 7505-7511. [CrossRef] [PubMed]

41. Bottomly, D.; Kyler, S.L.; McWeeney, S.K.; Yochum, G.S. Identification of \{beta\}-catenin binding regions in colon cancer cells using ChIP-Seq. Nucleic Acids Res. 2010, 38, 5735-5745. [CrossRef] [PubMed]

42. Hatzis, P.; van der Flier, L.G.; van Driel, M.A.; Guryev, V.; Nielsen, F.; Denissov, S.; Nijman, I.J.; Koster, J.; Santo, E.E.; Welboren, W.; et al. Genome-wide pattern of TCF7L2/TCF4 chromatin occupancy in colorectal cancer cells. Mol. Cell. Biol. 2008, 28, 2732-2744. [CrossRef] [PubMed]

43. Norton, L.; Fourcaudot, M.; Abdul-Ghani, M.A.; Winnier, D.; Mehta, F.F.; Jenkinson, C.P.; Defronzo, R.A. Chromatin occupancy of transcription factor 7-like 2 (TCF7L2) and its role in hepatic glucose metabolism. Diabetologia 2011, 54, 3132-3142. [CrossRef] [PubMed]

44. Duval, A.; Rolland, S.; Tubacher, E.; Bui, H.; Thomas, G.; Hamelin, R. The human T-cell transcription factor-4 gene: Structure, extensive characterization of alternative splicings, and mutational analysis in colorectal cancer cell lines. Cancer Res. 2000, 60, 3872-3879. [PubMed]

45. Van de Wetering, M.; Castrop, J.; Korinek, V.; Clevers, H. Extensive alternative splicing and dual promoter usage generate Tcf-1 protein isoforms with differential transcription control properties. Mol. Cell. Biol. 1996, 16, 745-752. [CrossRef] [PubMed]

46. Weise, A.; Bruser, K.; Elfert, S.; Wallmen, B.; Wittel, Y.; Wohrle, S.; Hecht, A. Alternative splicing of TCF7L2 transcripts generates protein variants with differential promoter-binding and transcriptional activation properties at Wnt/beta-catenin targets. Nucleic Acids Res. 2010, 38, 1964-1981. [CrossRef] [PubMed]

47. Ravindranath, A.J.; Cadigan, K.M. Structure-function analysis of the C-clamp of TCF/Pangolin in Wnt/ss-catenin signaling. PLoS ONE 2014, 9, e86180. [CrossRef] [PubMed]

48. Chang, M.V.; Chang, J.L.; Gangopadhyay, A.; Shearer, A.; Cadigan, K.M. Activation of wingless targets requires bipartite recognition of DNA by TCF. Curr. Biol. 2008, 18, 1877-1881. [CrossRef] [PubMed]

49. Hoverter, N.P.; Ting, J.H.; Sundaresh, S.; Baldi, P.; Waterman, M.L. A Wnt/p21 circuit directed by the C-clamp, a sequence-specific DNA binding domain in TCFs. Mol. Cell. Biol. 2012, 32, 3648-3662. [CrossRef] [PubMed]

50. Grishin, N.V. Treble clef finger-a functionally diverse zinc-binding structural motif. Nucleic Acids Res. 2001, 29, 1703-1714. [CrossRef] [PubMed]

51. Krishna, S.S.; Majumdar, I.; Grishin, N.V. Structural classification of zinc fingers: Survey and summary. Nucleic Acids Res. 2003, 31, 532-550. [CrossRef] [PubMed]

52. Laity, J.H.; Lee, B.M.; Wright, P.E. Zinc finger proteins: New insights into structural and functional diversity. Curr. Opin. Struct. Biol. 2001, 11, 39-46. [CrossRef] 
53. Hoverter, N.P.; Zeller, M.D.; McQuade, M.M.; Garibaldi, A.; Busch, A.; Selwan, E.M.; Hertel, K.J.; Baldi, P.; Waterman, M.L. The TCF C-clamp DNA binding domain expands the Wnt transcriptome via alternative target recognition. Nucleic Acids Res. 2014, 42, 13615-13632. [CrossRef] [PubMed]

54. Bhambhani, C.; Ravindranath, A.J.; Mentink, R.A.; Chang, M.V.; Betist, M.C.; Yang, Y.X.; Koushika, S.P.; Korswagen, H.C.; Cadigan, K.M. Distinct DNA binding sites contribute to the TCF transcriptional switch in C. elegans and drosophila. PLoS Genet. 2014, 10, e1004133. [CrossRef] [PubMed]

55. Archbold, H.C.; Broussard, C.; Chang, M.V.; Cadigan, K.M. Bipartite recognition of DNA by Tcf/Pangolin is remarkably flexible and contributes to transcriptional responsiveness and tissue specificity of wingless signaling. PLoS Genet. 2014, 10, e1004591. [CrossRef] [PubMed]

56. Hecht, A.; Stemmler, M.P. Identification of a promoter-specific transcriptional activation domain at the c terminus of the wnt effector protein T-cell factor 4. J. Biol. Chem. 2003, 278, 3776-3785. [CrossRef] [PubMed]

57. Cadigan, K.M.; Peifer, M. Wnt signaling from development to disease: Insights from model systems. Cold Spring Harb. Perspect. Biol. 2009, 1, a002881. [CrossRef] [PubMed]

58. Hikasa, H.; Ezan, J.; Itoh, K.; Li, X.; Klymkowsky, M.W.; Sokol, S.Y. Regulation of TCF3 by Wnt-dependent phosphorylation during vertebrate axis specification. Dev. Cell 2010, 19, 521-532. [CrossRef] [PubMed]

59. Kim, C.H.; Oda, T.; Itoh, M.; Jiang, D.; Artinger, K.B.; Chandrasekharappa, S.C.; Driever, W.; Chitnis, A.B. Repressor activity of Headless/Tcf3 is essential for vertebrate head formation. Nature 2000, 407, 913-916. [PubMed]

60. Shah, M.; Rennoll, S.A.; Raup-Konsavage, W.M.; Yochum, G.S. A dynamic exchange of TCF3 and TCF4 transcription factors controls myc expression in colorectal cancer cells. Cell Cycle 2015, 14, 323-332. [CrossRef] [PubMed]

61. Yi, F.; Pereira, L.; Hoffman, J.A.; Shy, B.R.; Yuen, C.M.; Liu, D.R.; Merrill, B.J. Opposing effects of Tcf3 and Tcf1 control wnt stimulation of embryonic stem cell self-renewal. Nat. Cell Biol. 2011, 13, 762-770. [CrossRef] [PubMed]

62. Blauwkamp, T.A.; Chang, M.V.; Cadigan, K.M. Novel TCF-binding sites specify transcriptional repression by Wnt signalling. EMBO J. 2008, 27, 1436-1446. [CrossRef] [PubMed]

63. Zhang, C.U.; Blauwkamp, T.A.; Burby, P.E.; Cadigan, K.M. Wnt-mediated repression via bipartite DNA recognition by TCF in the drosophila hematopoietic system. PLoS Genet. 2014, 10, e1004509. [CrossRef] [PubMed]

64. Wallmen, B.; Schrempp, M.; Hecht, A. Intrinsic properties of Tcf1 and Tcf4 splice variants determine cell-type-specific Wnt/beta-catenin target gene expression. Nucleic Acids Res. 2012, 40, 9455-9469. [CrossRef] [PubMed]

65. Boeckle, S.; Pfister, H.; Steger, G. A new cellular factor recognizes e2 binding sites of papillomaviruses which mediate transcriptional repression by e2. Virology 2002, 293, 103-117. [CrossRef] [PubMed]

66. Hasegawa, R.; Tomaru, Y.; de Hoon, M.; Suzuki, H.; Hayashizaki, Y.; Shin, J.W. Identification of ZNF395 as a novel modulator of adipogenesis. Exp. Cell Res. 2013, 319, 68-76. [CrossRef] [PubMed]

67. Tanaka, K.; Shouguchi-Miyata, J.; Miyamoto, N.; Ikeda, J.E. Novel nuclear shuttle proteins, HDBP1 and HDBP2, bind to neuronal cell-specific cis-regulatory element in the promoter for the human Huntington's disease gene. J. Biol. Chem. 2004, 279, 7275-7286. [CrossRef] [PubMed]

68. Yamamoto, M.; Watt, C.D.; Schmidt, R.J.; Kuscuoglu, U.; Miesfeld, R.L.; Goldhamer, D.J. Cloning and characterization of a novel myod enhancer-binding factor. Mech. Dev. 2007, 124, 715-728. [CrossRef] [PubMed]

69. Knight, J.B.; Eyster, C.A.; Griesel, B.A.; Olson, A.L. Regulation of the human GLUT4 gene promoter: Interaction between a transcriptional activator and myocyte enhancer factor 2a. Proc. Natl. Acad. Sci. USA 2003, 100, 14725-14730. [CrossRef] [PubMed]

70. Sparling, D.P.; Griesel, B.A.; Weems, J.; Olson, A.L. GLUT4 enhancer factor (GEF) interacts with MEF2A and HDAC5 to regulate the GLUT4 promoter in adipocytes. J. Biol. Chem. 2008, 283, 7429-7437. [CrossRef] [PubMed]

71. Anderson, C.A.; Boucher, G.; Lees, C.W.; Franke, A.; D’Amato, M.; Taylor, K.D.; Lee, J.C.; Goyette, P.; Imielinski, M.; Latiano, A.; et al. Meta-analysis identifies 29 additional ulcerative colitis risk loci, increasing the number of confirmed associations to 47. Nat. Genet. 2011, 43, 246-252. [CrossRef] [PubMed]

72. Franke, A.; McGovern, D.P.; Barrett, J.C.; Wang, K.; Radford-Smith, G.L.; Ahmad, T.; Lees, C.W.; Balschun, T.; Lee, J.; Roberts, R.; et al. Genome-wide meta-analysis increases to 71 the number of confirmed Crohn's disease susceptibility loci. Nat. Genet. 2010, 42, 1118-1125. [CrossRef] [PubMed] 
73. Yazdani, U.; Huang, Z.; Terman, J.R. The glucose transporter (GLUT4) enhancer factor is required for normal wing positioning in Drosophila. Genetics 2008, 178, 919-929. [CrossRef] [PubMed]

74. Jordanovski, D.; Herwartz, C.; Pawlowski, A.; Taute, S.; Frommolt, P.; Steger, G. The hypoxia-inducible transcription factor ZNF395 is controlled by IkB kinase-signaling and activates genes involved in the innate immune response and cancer. PLoS ONE 2013, 8, e74911. [CrossRef] [PubMed]

75. Goodarzi, H.; Zhang, S.; Buss, C.G.; Fish, L.; Tavazoie, S.; Tavazoie, S.F. Metastasis-suppressor transcript destabilization through TARBP2 binding of mRNA hairpins. Nature 2014, 513, 256-260. [CrossRef] [PubMed]

76. Pang, F.; Zha, R.; Zhao, Y.; Wang, Q.; Chen, D.; Zhang, Z.; Chen, T.; Yao, M.; Gu, J.; He, X. MiR-525-3p enhances the migration and invasion of liver cancer cells by downregulating ZNF395. PLOS ONE 2014, 9, e90867. [CrossRef] [PubMed]

77. Minster, R.L.; Sanders, J.L.; Singh, J.; Kammerer, C.M.; Barmada, M.M.; Matteini, A.M.; Zhang, Q.; Wojczynski, M.K.; Daw, E.W.; Brody, J.A.; et al. Genome-wide association study and linkage analysis of the healthy aging index. J. Gerontol. A Biol. Sci. Med. Sci. 2015, 70, 1003-1008. [CrossRef] [PubMed]

78. Fearon, E.R. Molecular genetics of colorectal cancer. Annu. Rev. Pathol. 2011, 6, 479-507. [CrossRef] [PubMed]

79. Najdi, R.; Holcombe, R.F.; Waterman, M.L. Wnt signaling and colon carcinogenesis: Beyond APC. J. Carcinog. 2011, 10, 5. [CrossRef] [PubMed]

80. Schuijers, J.; Mokry, M.; Hatzis, P.; Cuppen, E.; Clevers, H. Wnt-induced transcriptional activation is exclusively mediated by TCF/LEF. EMBO J. 2014, 33, 146-156. [CrossRef] [PubMed]

81. Korinek, V.; Barker, N.; Moerer, P.; van Donselaar, E.; Huls, G.; Peters, P.J.; Clevers, H. Depletion of epithelial stem-cell compartments in the small intestine of mice lacking TCF-4. Nat. Genet. 1998, 19, 379-383. [PubMed]

82. Van Es, J.H.; Haegebarth, A.; Kujala, P.; Itzkovitz, S.; Koo, B.K.; Boj, S.F.; Korving, J.; van den Born, M.; van Oudenaarden, A.; Robine, S.; et al. A critical role for the Wnt effector Tcf4 in adult intestinal homeostatic self-renewal. Mol. Cell. Biol. 2012, 32, 1918-1927. [CrossRef] [PubMed]

83. Xie, J.; Xiang, D.B.; Wang, H.; Zhao, C.; Chen, J.; Xiong, F.; Li, T.Y.; Wang, X.L. Inhibition of Tcf-4 induces apoptosis and enhances chemosensitivity of colon cancer cells. PLoS ONE 2012, 7, e45617. [CrossRef] [PubMed]

84. Bass, A.J.; Lawrence, M.S.; Brace, L.E.; Ramos, A.H.; Drier, Y.; Cibulskis, K.; Sougnez, C.; Voet, D.; Saksena, G.; Sivachenko, A.; et al. Genomic sequencing of colorectal adenocarcinomas identifies a recurrent VTI1A-TCF7L2 fusion. Nat. Genet. 2011, 43, 964-968. [CrossRef] [PubMed]

85. Clevers, H.; Nusse, R. Wnt/beta-catenin signaling and disease. Cell 2012, 149, 1192-1205. [CrossRef] [PubMed]

86. Atcha, F.A.; Munguia, J.E.; Li, T.W.; Hovanes, K.; Waterman, M.L. A new beta-catenin-dependent activation domain in T cell factor. J. Biol. Chem. 2003, 278, 16169-16175. [CrossRef] [PubMed]

87. Nakano, N.; Kato, M.; Itoh, S. Regulation of the tmepai promoter by TCF7L2: The c-terminal tail of TCF7L2 is essential to activate the TMEPAI gene. J. Biochem. 2016, 159, 27-30. [CrossRef] [PubMed]

88. Nakano, N.; Itoh, S.; Watanabe, Y.; Maeyama, K.; Itoh, F.; Kato, M. Requirement of TCF7L2 for TGF-beta-dependent transcriptional activation of the TMEPAI gene. J. Biol. Chem. 2010, 285, 38023-38033. [CrossRef] [PubMed]

89. Watanabe, Y.; Itoh, S.; Goto, T.; Ohnishi, E.; Inamitsu, M.; Itoh, F.; Satoh, K.; Wiercinska, E.; Yang, W.; Shi, L.; et al. TMEPAI, a transmembrane TGF-beta-inducible protein, sequesters smad proteins from active participation in tgf-beta signaling. Mol. Cell. Biol. 2010, 37, 123-134.

90. Reichling, T.; Goss, K.H.; Carson, D.J.; Holdcraft, R.W.; Ley-Ebert, C.; Witte, D.; Aronow, B.J.; Groden, J. Transcriptional profiles of intestinal tumors in APC(Min) mice are unique from those of embryonic intestine and identify novel gene targets dysregulated in human colorectal tumors. Cancer Res. 2005, 65, 166-176. [PubMed]

91. Brunschwig, E.B.; Wilson, K.; Mack, D.; Dawson, D.; Lawrence, E.; Willson, J.K.; Lu, S.; Nosrati, A.; Rerko, R.M.; Swinler, S.; et al. PMEPA1, a transforming growth factor-beta-induced marker of terminal colonocyte differentiation whose expression is maintained in primary and metastatic colon cancer. Cancer Res. 2003, 63, 1568-1575. [PubMed]

92. Giannini, G.; Ambrosini, M.I.; Di Marcotullio, L.; Cerignoli, F.; Zani, M.; MacKay, A.R.; Screpanti, I.; Frati, L.; Gulino, A. EGF- and cell-cycle-regulated STAG1/PMEPA1/ERG1.2 belongs to a conserved gene family and is overexpressed and amplified in breast and ovarian cancer. Mol. Carcinog. 2003, 38, 188-200. [CrossRef] [PubMed] 
93. Rae, F.K.; Hooper, J.D.; Nicol, D.L.; Clements, J.A. Characterization of a novel gene, STAG1/PMEPA1, upregulated in renal cell carcinoma and other solid tumors. Mol. Carcinog. 2001, 32, 44-53. [CrossRef] [PubMed]

94. Vo Nguyen, T.T.; Watanabe, Y.; Shiba, A.; Noguchi, M.; Itoh, S.; Kato, M. TMEPAI/PMEPA1 enhances tumorigenic activities in lung cancer cells. Cancer Sci. 2014, 105, 334-341. [CrossRef] [PubMed]

95. Sanchez-Tillo, E.; de Barrios, O.; Valls, E.; Darling, D.S.; Castells, A.; Postigo, A. ZEB1 and TCF4 reciprocally modulate their transcriptional activities to regulate Wnt target gene expression. Oncogene 2015, 34, 5760-5770. [CrossRef] [PubMed]

96. Gregorieff, A.; Grosschedl, R.; Clevers, H. Hindgut defects and transformation of the gastro-intestinal tract in tcf4(-/-)/tcf1(-/-) embryos. EMBO J. 2004, 23, 1825-1833. [CrossRef] [PubMed]

97. Su, L.K.; Kinzler, K.W.; Vogelstein, B.; Preisinger, A.C.; Moser, A.R.; Luongo, C.; Gould, K.A.; Dove, W.F. Multiple intestinal neoplasia caused by a mutation in the murine homolog of the APC gene. Science 1992, 256, 668-670. [CrossRef] [PubMed]

98. Hinoi, T.; Akyol, A.; Theisen, B.K.; Ferguson, D.O.; Greenson, J.K.; Williams, B.O.; Cho, K.R.; Fearon, E.R. Mouse model of colonic adenoma-carcinoma progression based on somatic APC inactivation. Cancer Res. 2007, 67, 9721-9730. [CrossRef] [PubMed]

(C) 2016 by the authors; licensee MDPI, Basel, Switzerland. This article is an open access article distributed under the terms and conditions of the Creative Commons Attribution (CC-BY) license (http://creativecommons.org/licenses/by/4.0/). 